\title{
Isolation and identification of indigenous Arbuscular Mycorrhizal Fungi (AMF) of forest clove rhizosphere from Maluku, Indonesia
}

\author{
ASRI SUBKHAN MAHULETTE ${ }^{1,2, v}$, ANGGRA ALFIAN ${ }^{2,3}$, ABDUL KARIM KILKODA ${ }^{1}$, \\ IMELDA JEANETTE LAWALATA ${ }^{1}$, DESSY ARIY ANI MARASABESSY ${ }^{1}$, VILMA LAURIEN TANASALE ${ }^{1}$, \\ MARLITA HERLIN MAKARUKU ${ }^{1}$ \\ ${ }^{1}$ Department of Agrotechnology, Faculty of Agriculture, Universitas Pattimura. Jl. Ir. Putuhena, Poka, Ambon 97233, Maluku, Indonesia \\ vemail: mahulette_07@yahoo.co.id. \\ ${ }^{2}$ Aksi Konservasi Celebica, Palopo 91926, South Sulawesi, Indonesia \\ ${ }^{3}$ Faculty of Health, Agriculture and Marine Science, Universitas Muhammadiyah Palopo. Palopo 91959, South Sulawesi, Indonesia.
}

Manuscript received: 18 July 2021. Revision accepted: 31 July 2021.

\begin{abstract}
Mahulette AS, Alfian A, Kilkoda KA, Lawalata IJ, Marasabessy DA, Tanasale VL, Makaruku MH. 2021. Isolation and identification of indigenous Arbuscular Mycorrhizal Fungi (AMF) of forest clove rhizosphere from Maluku, Indonesia. Biodiversitas 22: 3613-3619. Forest clove is classified as wild-type and endemic to the Maluku (Moluccas) Islands, Indonesia. The different condition of growing areas causes various types of Arbuscular Mycorrhizal Fungi (AMF) associated with forest clove. The study aimed to identify and obtain indigenous AMF inoculums from the forest clove rhizosphere from two distribution areas in Maluku. The results of AMF identification found two types of spores from the genus Glomus in the rhizosphere of forest cloves from Ambon Island with a spore density of 35/50 g of soil. In comparison, three spores were found in Seram Island, two from the genus Scutellospora and one from the Acaulospora. With an overall spore density of 5/50 g of soil. After culture trapping, there was a change in type and an increase in spore density in soil samples from the rhizosphere of the two forest clove distribution areas. Soil samples from Ambon after trapping culture obtained two new types of spores from the genus Acaulospora with a total spore number of 57/50 $\mathrm{g}$ soil while in soil samples from Seram found three new types of spores from the genus Glomus with a total spore count of 104/50 $\mathrm{g}$ of soil.
\end{abstract}

Keywords: AMF, endomycorrhizae, forest clove, Maluku

\section{INTRODUCTION}

Clove (Syzygium aromaticum L.) is one of the leading commodities in Maluku (Moluccas) (Alfian et al. 2019; Mahulette et al. 2019a; Hariyadi et al. 2020). However, clove production is still around $40-60 \%$ of the potential production of plants (Mahulette et al. 2019b). Chemical fertilizers can increase the productivity of cloves, but their use in the long term can harm the environment and the quality of crop yields. Biological agents such as mycorrhizae can be applied to increase productivity and quality of clove in the long term (Putri et al. 2016; Thomsen et al. 2021). Arbuscular mycorrhizal fungi (AMF) are symbiotic with plants (Wang et al. 2017; Meng et al. 2021). AMF can facilitate the uptake of mineral nutrients such as phosphorus and nitrogen by increasing the absorption surface area and mobilizing nutrients (Wang et al. 2017; Ishaq et al. 2021; Nacoon et al. 2021).

AMF is classified into the phylum Glomeromycota, class Glomeromycetes, four orders Glomerales, Diversisporales, Paraglomerales, Archaeosporales with 11 families, and 17 genera (Tuheteru et al. 2019; Ibou et al. 2021). AMF can be used as a biological agent because it assists nutrient absorption, protection against root pathogens infections, increasing water availability for plants, and increasing growth hormones (Setyaningsih et al. 2020; Ishaq et al. 2021; Meng et al. 2021; Nacoon et al. 2021). The use of AMF in cloves has previously been reported by Putri et al. (2016) by using mycorrhizal micover. The use of indigenous AMF derived from the rhizosphere of the clove has never been reported.

Forest clove is an endemic plant from the Maluku Islands (Hariyadi et al. 2019; Mahulette et al. 2020a, 2019b, 2020b, 2019a). The fast growth and robust root system allow the association of this clove with AMF (Hariyadi et al. 2019; Mahulette et al. 2019b, 2020a). AMF from the forest clove rhizosphere has the potential to be explored as a biological agent in supporting clove productivity. The distribution area of forest cloves in Maluku includes Ambon Island (Hitulama and Hitumesing villages) and Seram Island (Latu and Hualooi villages) (Mahulette et al. 2019a, 2019b, 2020a). It is possible to find mycorrhizae with different types and densities in two different distribution areas. According to Asmelash et al. (2021) and Thomsen et al. (2021), the presence of AMF is strongly influenced by the type of host plant, spore type, and environmental factors such as soil.

The presence of AMF in forest clove rhizosphere has not been studied. The AMF can be used as a biological agent to support the growth and productivity of cloves. Therefore, the isolation, identification, and propagation of AMF from the rhizosphere of forest cloves need to be carried out. The study aims to obtain a forest clove indigenous AMF inoculum to be used as a biological agent in supporting the growth and productivity of clove in the future. 


\section{MATERIALS AND METHODS}

\section{AMF observations on forest clove roots from nature}

Identification of AMF in forest clove root from nature samples was carried out at the Laboratory Pusat Antar Universitas (PAU) IPB University, Bogor, Indonesia. Preliminary identification was carried out to prove the association of forest clove with AMF before isolation. Preliminary identification of root samples was carried out through root staining techniques. The roots were cleaned from nature and then soaked in a $10 \%(\mathrm{w} / \mathrm{v}) \mathrm{KOH}$ solution for one day until they looked white. The roots were removed and washed under running water, soaked in $2 \%$ $\mathrm{HCl}$ solution for 3-4 minutes without washing. Furthermore, the roots were immersed in a trypan blue solution (trypan blue $0.25 \mathrm{~g}$ in $475 \mathrm{~mL}$ of lactic acid and 25 $\mathrm{mL}$ of distilled water) for one day. The roots were cut \pm 1 $\mathrm{cm}$ and placed in a row on the object-glass, coated with a cover glass (one object-glass for ten root pieces). Subsequently, the root sections were observed with a microscope, and the colonized root sections were recorded, which were characterized by the presence of hyphae, arbuscular, and vesicles.

\section{Soil sampling}

Soil sampling for isolation and identification of mycorrhizae was carried out from areas around the roots (rhizosphere) of forest clove in two distribution areas of Maluku, namely Ambon Island and Seram Island. Soil samples from the forest clove rhizosphere in each region were taken at 5 points diagonally in an area of $20 \mathrm{~m} \times 20$ $\mathrm{m}$. Each point of the forest clove rhizosphere was taken with a depth of $0-20 \mathrm{~cm}$ from the ground surface and then composited. A sample of $500 \mathrm{~g}$ of composite soil was put into a labeled plastic bag for isolation and identification of AMF (Nusantara et al. 2012).

\section{Spores isolation and AMF identification}

Isolation and identification of AMF spores were carried out at the Mycorrhizal Laboratory, Department of Silviculture-IPB University. AMF isolation was carried out to separate spores from soil samples so that AMF identification could be carried out to determine the AMF spore genus. Identification of AMF spores referred to filtercast technique and followed by centrifugation Nusantara et al. (2012). The procedure for this pour-filter technique is to mix $50 \mathrm{~g}$ of soil sample with $200-300 \mathrm{~mL}$ of water, then stir until the soil grains are crushed. Furthermore, it was filtered in a set of stratified sieves with sizes of $410 \mu \mathrm{m}$, $125 \mu \mathrm{m}$, and $45 \mu \mathrm{m}$, respectively, from top to bottom. The top filter is sprayed with tap water to make it easier for spores to escape. Then the top filter was removed, and some of the soil remaining on the bottom filter was transferred to a centrifuge tube. The spore isolation of the pour-filter technique was followed by the centrifugation technique of Nusantara et al. (2012).

The filter results in a centrifuge tube were added with $60 \%$ glucose using a pipette. The centrifuge tube was tightly closed and centrifuged at $2500 \mathrm{rpm}$ for 5 minutes. Furthermore, the supernatant and pure water were poured into a plastic funnel that had been lined with millipore paper. The water would penetrate the paper and fall into the glass bottle, and then the filtered spores were washed/cleaned with water from a spray bottle to prevent spore lysis. Then the millipore paper containing the spores was folded and put back into the film bottle for identification purposes. Millipore paper was removed with tweezers, opened on a petri dish, and then observed under a microscope to calculate spore density and spore types according to size, shape, color, and other ornaments. Spore density is calculated by the formula:

Spore Density $=\frac{\text { number of spore }}{\text { weight of analyzed soil }}$

\section{AMF Trapping}

AMF trapping was carried out in the greenhouse of the Department of Silviculture IPB University. The trapping technique follows Nusantara et al. (2012) method using small culture pots with a diameter of $6 \mathrm{~cm}$. The soil media mixture of $\pm 50 \mathrm{~g}$ of soil samples and $\pm 120 \mathrm{~g}$ of zeolite $1-2$ $\mathrm{mm}$. The culture pot was filled with zeolite up to half the pot volume $(100 \mathrm{~g})$, then added soil sample $(50 \mathrm{~g})$ and covered with zeolite to half the pot volume (50 g), so that the planting medium was composed of zeolite-soil samplezeolite.

Pueraria javanica seeds as host plants are first soaked in Bayclin solution for 5-10 minutes to sterilize the surface. Then the seeds were soaked in warm water for \pm 24 hours to break the dormancy. Furthermore, the seeds were planted in the nursery for \pm ten days. After that, the sprouts were transferred directly to culture pots. Culture preservation includes watering, providing nutrients, and controlling pests. The nutrient solution used was red hyponex (25-20-20) with $1 \mathrm{~g}$ per 2 liters of water concentration. The provision of the nutrient solution was carried out every week as much as $\pm 20 \mathrm{~mL}$ per culture pot. After the culture is six months old, harvesting is carried out to obtain spores. The variables observed at this stage were the type of spores and the number of spores per $50 \mathrm{~g}$ of growing media.

\section{Data analysis}

Isolation and identification of AMF were carried out on soil samples from the forest clove rhizosphere area from two forest clove distribution locations in Maluku and soil samples from trapping cultures. The data obtained on the type and density of AMF spores were analyzed descriptively.

\section{RESULTS AND DISCUSSION}

\section{Observation of AMF colonization on forest clove root samples from nature}

The results of preliminary observations confirmed that forest cloves are associated with endomycorrhizae (Figure 1). The observations of root samples showed arbuscular, vesicle, hyphae, and spore. Endomycorrhizal fungi are also known as Arbuscular Mycorrhizal Fungi (AMF) or 
vesicular mycorrhizae (Lara-Capistran et al. 2021; Meng et al. 2021; Sukmawati et al. 2021). They form distinctive oval structures called vesicles and branched called arbuscular. Hyphae and arbuscular structures function in exchanging nutrients between plants and their hosts, while the vesicle structure serves as a storage place for food reserves (Piliarová et al. 2019; Sukmawati et al. 2021). AMF is characterized by hyphae that develop around the roots but do not cover the root surface or a mantle. Instead, AMF hyphae penetrate the root cortex and develop arbuscular and vesicle structures.

Arbuscular Mycorrhizal Fungi (AMF) is a mutualistic symbiosis between fungi and plant roots (Lara-Capistran et al. 2021). AMF facilitates the uptake of phosphorus and nitrogen by increasing the absorption surface area and mobilizing nutrients. Plants associated with mycorrhizae perform as essential carbon sources for mycorrhizal growth (Wang et al. 2017). AMF plays a role in increasing the absorption of nutrients, especially phosphorus, making soil aggregates more stable, as a bio-regulatory agent, increasing groundwater absorption and as a biological control agent (biocontrol) as well as being able to absorb and store heavy metals in the vacuoles, vesicles, and hyphae (Prayudyaningsih et al. 2019; Setyaningsih et al. 2020; Chaiya et al. 2021; Ishaq et al. 2021; Meng et al. 2021; Nacoon et al. 2021; Wu et al. 2021).

\section{Isolation and identification of AMF spores in forest clove rhizosphere.}

The results of the isolation and identification of mycorrhizal spores in soil samples from the rhizosphere area in both forest clove distribution areas showed that there were variations in the type and density of spores. The identification results showed that the genus Glomus was only found in the soil samples from Ambon with a higher spore density (35 spores). In comparison, the soil samples from Seram only found the genus Scutellospora and Acaulospora with low spore density (5 spores) (Table 1). The condition of the Ambon region supports the AMF colonization process of the Glomus. It supports the germination process for the formation of new spores. The genus Glomus is classified as a mycorrhizal type with a wide distribution found in almost all ecosystems (Ibou et al. 2021; Lara-Capistran et al. 2021; Sukmawati et al. 2021). While the genera Scutellospora and Acaulospora have limited distribution (Ibou et al. 2021; Lara-Capistran et al. 2021; Sukmawati et al. 2021).

The different types and densities of AMF spores in the two regions were strongly influenced by environmental factors, especially climate and soil (Alimi et al. 2021; Meng et al. 2021; Nacoon et al. 2021; Piliarová et al. 2019). Piliarová et al. (2019) and Nacoon et al. (2021) stated that the presence of AMF is strongly influenced by the type of host plant, spore type, and environmental factors such as soil. Soil is the most influential factor in the different types and spore density (Table 2). Soil factors such as soil texture and structure, $\mathrm{N}$ and $\mathrm{P}$ nutrients, water, and $\mathrm{pH}$ significantly affect the distribution of mycorrhizae (Husna et al. 2015; Lara-Capistran et al. 2021; Nacoon et al. 2021; Piliarová et al. 2019).

The clay texture with a $\mathrm{pH}$ close to neutral on the soil from Ambon caused the mycorrhizae to be dominated by the Glomus. In contrast, the sandy clay texture with a slightly acidic $\mathrm{pH}$ in the Seram soil was dominated by the Acaulospora and Scutellospora. Soils dominated by the clay fraction are suitable for the development of Glomus, which has a small diameter size, while the sandy texture is suitable for mycorrhizae which have larger spore sizes such as Acaulospora, Scutelospora, and Gygaspora (Ibou et al. 2021). $\mathrm{pH}>5.0$ is identified as suitable for Glomus mosseae (Suada et al. 2018; Ibou et al. 2021; Sukmawati et al. 2021). Acaulospora is more adaptive to acid soils with $\mathrm{pH}<5$ (Ibou et al. 2021).

\section{Isolation and identification of AMF spores from trapping culture}

The results of the trapping culture of soil from Ambon and Seram showed a change in types and spore density before and after trapping culture (Table 3). The results of trapping culture on soil samples from Ambon obtained three types of spores, namely Acaulospora sp.1, Acaulospora sp.2, and Glomus sp. 1. These results showed that the genus Glomus from 2 types of spores was reduced to 1 type of spore after trapping culture and adding two new types of spores from the genus Acaulospora. The same condition also occurred in the soil sample from Seram after trapping culture, where three genera Glomus were obtained and the previous two genera, Scutellospora and Acaulospora, were not found.

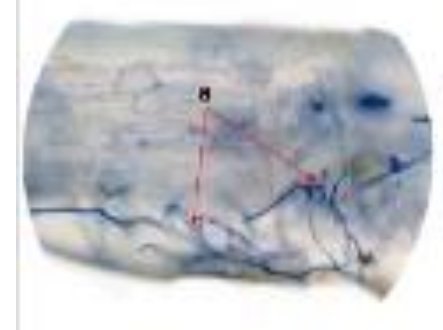

A
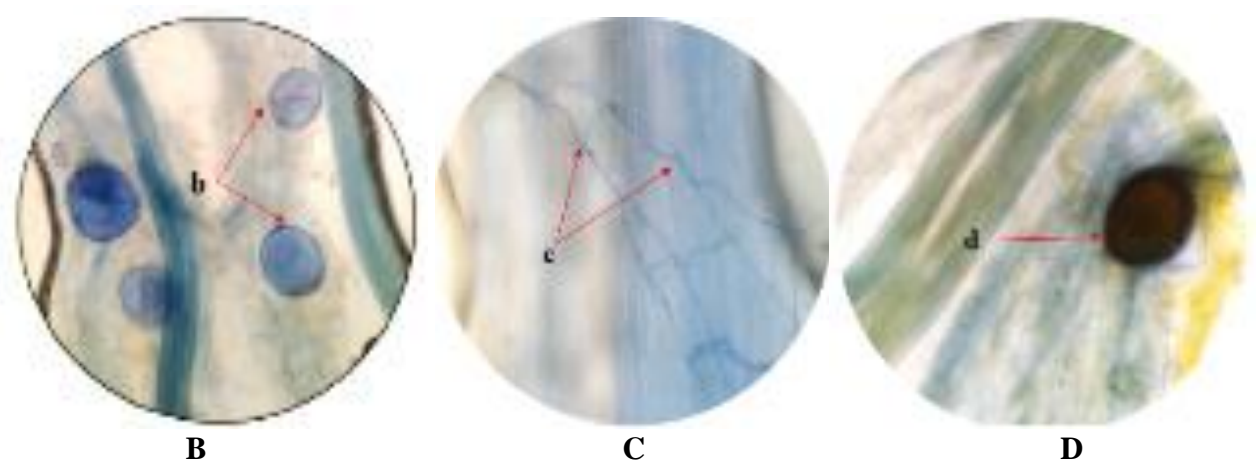

Figure 1. Endomycorrhizal infection in forest clove roots (AMF). A. Arbuscule structures, B. Vesicles, C. Hyphae, D. Spores. 
Table 1. Type and density of AMF spores from nature sample

\begin{tabular}{|c|c|c|c|c|}
\hline Name & Spore type & Morphological description & $\begin{array}{l}\text { No. of spores/ } \\
50 \text { g soil }\end{array}$ & Location \\
\hline Glomus sp.1 & & $\begin{array}{l}\text { Spores are reddish-brown, loose clusters, } 80- \\
90 \times 80-90 \mu \mathrm{m} \text { in diameter. }\end{array}$ & 32 & Ambon \\
\hline \multirow[t]{2}{*}{ Glomus sp. 2} & & $\begin{array}{l}\text { The spore has a complex sporocarp, loose, } \\
\text { dark brown and spore diameter } 400 \times 400 \\
\mu \mathrm{m} \text {. }\end{array}$ & 3 & Ambon \\
\hline & & Total spores $/ 50 \mathrm{~g}$ soil from Ambon & 35 & \\
\hline Scutellospora sp.1 & & $\begin{array}{l}\text { The spores are transparent, round, } 300 \times 300 \\
\mu \mathrm{m} \text { in diameter; there is a bulbous suspensor } \\
\text { and a yellow-brown germination shield (on } \\
\text { mature spores). }\end{array}$ & 2 & Seram \\
\hline Scutellospora sp. 2 & & $\begin{array}{l}\text { Spores are transparent, oblong, with a } 420 \mathrm{x} \\
460 \mu \mathrm{m} \text {; there is a suspensory boulbus, } \\
\text { which has a clear spore-wall and germinal } \\
\text { wall. }\end{array}$ & 2 & Seram \\
\hline \multirow[t]{2}{*}{ Acaulospora spp } & & $\begin{array}{l}\text { Spores are transparent, spore-wall ornate, } \\
300 \times 300 \mu \mathrm{m} \text { diameter. }\end{array}$ & 1 & Seram \\
\hline & & Total spores/50 g soil from Seram & 5 & \\
\hline
\end{tabular}

Table 2. Ecological factors at the location of forest cloves in Maluku

\begin{tabular}{lcc}
\hline \multirow{2}{*}{ Ecological Factors } & \multicolumn{2}{c}{ Area } \\
\cline { 2 - 3 } Climate & Ambon & Seram \\
Rainfall (mm/year) & 5401.00 & 2783.70 \\
Daily air temperature $\left(\mathrm{C}^{\circ}\right)$ & 27.03 & 26.90 \\
Daily air humidity $(\%)$ & 85.60 & 87.00 \\
Soil & & \\
Texture & $\mathrm{Clay}$ & Sandy clay \\
pH & 6.56 & 5.36 \\
Water content $(\%)$ & 4.40 & 1.72 \\
$\mathrm{C}$ organic $(\%)$ & 2.38 & 2.79 \\
N-Total $(\%)$ & 0.25 & 0.27 \\
$\mathrm{P}_{2} \mathrm{O} 5(\mathrm{ppm})$ & 29.87 & 6.50 \\
$\mathrm{~K}_{2} \mathrm{O}(\mathrm{ppm})$ & 88.52 & 27.84 \\
\hline
\end{tabular}

The change in spore type before and after trapping culture is caused by some spore types inoculated during the trapping culture that did not develop. The undeveloped spore types consisted of 2 genera, Glomus in the soil sample from Ambon and two Scutelospora, and one genus Acaulospora in the soil sample from Seram. The type of spore is only germinated to hyphae but then dies because it does not infect the host plant in trapping culture. Mycorrhizal hyphae could only survive for 20-30 days without association with the host plant (Sukmawati et al. 2021; Thomsen et al. 2021). The infectivity and effectiveness of mycorrhizae are primarily determined by biotic factors such as the type of mycorrhizae, the host plant, microbial interactions, the type of soil of the host plant, and the composition between fungi and abiotic factors such as environmental factors, especially soil 
(Piliarová et al. 2019; Lara-Capistran et al. 2021; Meng et al. 2021).

The addition of new spore types and densities in both soil samples after culture trapping was due to undercontrolled and stable greenhouse conditions. Some spores that had not germinated at the time of collection from the field germinated and formed new spores. Controlled and stable greenhouse conditions will increase the germination of spores that have not germinated before to increase the formation of new spores (Nacoon et al. 2021; Sukmawati et al. 2021). It is also supported by using the host plant Pueraria javanica for spore propagation in trapping cultures to encourage the germination of new spores that are compatible with the roots of the host plants. Pueraria javanica is widely used in inoculum propagation because it has many roots and is tolerant of acid and alkaline soil properties (Yusril and Burhanuddin 2018; Nurhayati 2019).

Tabel 2. Type and density of AMF spores from trapping culture

\begin{tabular}{|c|c|c|c|c|}
\hline Name & Spore type & Morphological description & $\begin{array}{l}\text { No. of spores/ } \\
50 \mathrm{~g} \text { soil }\end{array}$ & Location \\
\hline Acaulospra sp.1 & & $\begin{array}{l}\text { The spores are transparent, round, } 120-180 \mathrm{x} \\
120-180 \mu \mathrm{m} \text { in diameter, the spore-wall is } \\
\text { decorated with ornaments like spots. }\end{array}$ & 9 & Ambon \\
\hline Acaulospora sp. 2 & & $\begin{array}{l}\text { Spores are round, yellow-brown with large } \\
\text { size (240-300 x } 240-300 \mu \mathrm{m} \text { diameter), } \\
\text { spore-wall surface ornate like orange peel. }\end{array}$ & 6 & Ambon \\
\hline \multirow[t]{2}{*}{ Golumus sp.1 } & & $\begin{array}{l}\text { Spores are round, reddish-brown, } 90-120 \mathrm{x} \\
90-120 \mu \mathrm{m} \text { in diameter, visible germination } \\
\text { tube on hyphae attachment, forming only a } \\
\text { spore-wall layer. }\end{array}$ & 42 & Ambon \\
\hline & & Total spores/50 g soil from Ambon & 57 & \\
\hline Golumus sp. 1 & & $\begin{array}{l}\text { The spores are round, } 200 \times 200 \mu \mathrm{m} \text { in } \\
\text { diameter, yellow-brown and have a } \\
\text { pronounced spore-wall coating. }\end{array}$ & 18 & Seram \\
\hline Golumus sp. 2 & & $\begin{array}{l}\text { Spores are round, formed in closely spaced } \\
\text { series, } 120 \times 120 \mu \mathrm{m} \text { in diameter, forming } \\
\text { only a spore-wall layer. }\end{array}$ & 56 & Seram \\
\hline Golumus sp. 3 & & $\begin{array}{l}\text { Spores are formed in roots, oval, yellowish, } \\
120 \times 200 \mu \mathrm{m} \text { in diameter. }\end{array}$ & 30 & Seram \\
\hline & & Total spores $/ 50 \mathrm{~g}$ soil from Seram & 104 & \\
\hline
\end{tabular}


The results showed an increase in spore densities before and after culture trapping in both soil samples. The spore density in soil from Ambon increased from 35 to 57 spores $/ 50 \mathrm{~g}$ soil after culture trapping. The same increase also occurred in Seram soil, where there was an increase in spore density from 5 to 104 spores/50 g soil.

Trapping culture showed that the number of spores formed in the Seram sample was higher than Ambon. The genus Glomus has wide adaptability and has a wide host range to sporulate quickly during trapping culture. According to Piliarová et al. (2019) and Ibou et al. (2021) the genus Glomus is a type of spore with a wide host range and is dominantly found in various environmental conditions. Furthermore, according to Sukmawati et al. (2021) and Lara-Capistran et al. (2021), the distribution pattern of the AMF genus is different, where there are specific genera with a vast distribution, and there are genera with limited distribution. The genus that has the widest distribution is Glomus.

The conclusion of the study reported the types of AMF spores associated with forest clove plants. The results obtained information that found two types of spores from the genus Glomus in the forest clove rhizosphere area from Ambon Island with a spore density of $35 / 50 \mathrm{~g}$ soil. In comparison, three spores were found in Seram Island, namely two from the Scutellospora genus and one from Acaulospora, with an overall spore density of 5/50 $\mathrm{g}$ of soil. Trapping culture caused changes in spore type and increased spore density in soil samples from the rhizosphere of the two forest clove distribution areas.

\section{ACKNOWLEDGEMENTS}

The authors are grateful to the Indonesian Endowment Fund for Education (LPDP), Ministry of Finance, Indonesia for their financial support.

\section{REFERENCES}

Alfian A, Mahulette AS, Zainal M, Hardin, Bahrun AH. 2019. Morphological character of Raja Clove (Syzygium aromaticum L. Merr \& Perry.) native from Ambon Island. IOP Conf Ser Earth Environ Sci 343: 012150. DOI: 10.1088/1755-1315/343/1/012150.

Alimi AA, Adeleke R, Moteetee A. 2021. Soil environmental factors shape the rhizosphere arbuscular mycorrhizal fungal communities in South African indigenous legumes (Fabaceae). Biodiversitas 22 (5): 2466-2476. DOI: 10.13057/biodiv/d220503.

Asmelash F, Bekele T, Belay Z, Kebede F. 2021. Cordia africana but not Juniperus procera and Podocarpus falcatus respond positively to arbuscular mycorrhizal fungi at the early stages of seedling development. Biodiversitas 22 (5): 2971-2980. DOI:10.13057/biodiv/d220562.

Chaiya L, Lumyong S, Kumla J, Suwannarach N, Kiatsiriroat T. 2021. Isolation, characterization, and efficacy of actinobacteria associated with arbuscular mycorrhizal spores in promoting plant growth of chili (Capsicum flutescens L.). Microorganisms 9 (1274): 1-19. DOI:10.3390/ microorganisms9061274

Hariyadi, Mahulette AS, Yahya S, Wachjar A. 2020. Agro-morphologies and physicochemical properties of flower bud, stem and leaf oils in two clove varieties (Syzygium aromaticum L. Merr. and Perry.) originated from Ambon island. Chiang Mai Univ J Nat Sci 19 (3): 516-530. DOI: 10.12982/CMUJNS.2020.0034.
Hariyadi, Mahulette AS, Yahya S, Wachjar A. 2019. Measuring the potential of biomass, carbon storage, and carbon sink of forest cloves. I IOP Conf Ser Earth Environ Sci 399: 012063. DOI:10.1088/17551315/399/1/012063

Husna, Budi SW, Mansur I, Kusmana DC. 2015. Diversity of arbuscular mycorrhizal in the growth habitat of kayu kuku (Pericopsis mooniana Thw.) in Southeast Sulawesi. Pakistan J Biol Sci 18 (1): 1-10. DOI: 10.3923/pjbs.2015.1.10

Ibou D, Fatou N, Abdala D, Tatiana K-W, Francis DR, Kandioura N, Paul AJ, Aboubacry K. 2021. Diversity and spore density of arbuscular mycorrhizal fungi in the rhizosphere of Cowpea (Vigna unguiculata [L.] Walp.) cultivated in different soils in Senegal. J Anim Plant Sci 48 (1): 8552-8565. DOI: 10.35759/JAnmP1Sci.v48-1.1.

Ishaq L, Tae ASJA, Airthur MA, Bako PO. 2021. Effect of single and mixed inoculation of arbuscular mycorrhizal fungi and phosphorus fertilizer application on corn growth in calcareous soil. Biodiversitas 22 (4): 1920-1926. DOI:10.13057/biodiv/d220439.

Lara-Capistran L, Zulueta-Rodriguez R, Murillo-Amador B, VerdeciaAcosta DM, Hernandez-Montiel LG. 2021. Biodiversity of AM fungi in coffee cultivated on eroded soil. Agronomy 11 (567): 1-10. DOI: 10.3390/agronomy11030567.

Mahulette AS, Hariyadi, Yahya S, Wachjar A, Alfian A. 2019a. Morphological traits of Maluku native forest clove (Syzygium aromaticum L. Merr \& Perry.). J Trop Crop Sci 6 (2): 105-111. DOI: DOI: $10.4308 / \mathrm{hjb} .26 .4 .156$.

Mahulette AS, Hariyadi, Yahya S, Wachjar A, Marzuki I. 2019c. Morphoagronomical diversity of forest clove in Moluccas, Indonesia. Hayati J Biosci 26 (4): 156-162. DOI:10.4308/hjb.26.4.156.

Mahulette AS, Hariyadi, Yahya S, Wachjar A. 2020b. Physico-chemical properties of clove oil from three forest clove accession groups in Maluku. IOP Conf Ser: Earth Environ Sci 418: 012028 IOP. DOI: 10.1088/1755-1315/418/1/012028.

Mahulette AS, Alfian A, Zainal M, Nendissa JI, Wattimena AY, Tanasale VL, Makaruku MH, Laisina JKJ. 2020a. Growth of forest clove seedlings at different concentrations of paclobutrazol. IOP Conf Ser: Earth Environ Sci 575: 012081. DOI:10.1088/17551315/575/1/012081.

Meng L, Srivastava AK, Kuča K, Giri B, Rahman MM, Wu Q. 2021. Interaction between earthworms and arbuscular mycorrhizal fungi in plants: a review. Phyton (B. Aires) 90 (3): 687-699. DOI: $10.32604 /$ phyton.2021.015427.

Nacoon S, Jogloy S, Riddech N, Mongkolthanaruk W, Ekprasert J, Cooper J, Boonlue S. 2021. Combination of arbuscular mycorrhizal fungi and phosphate solubilizing bacteria on growth and production of Helianthus tuberosus under field condition. Sci Rep 11 (6501): 110. DOI:10.1038/s41598-021-86042-3.

Nurhayati. 2019. Perbanyakan mikoriza dengan metode kultur pot. Wahana Inov 8 (1): 8-13. [Indonesian]

Nusantara AD, Bertham YH, Mansur I. 2012. Bekerja Dengan Fungi Mikoriza Arbuskula. SEAMEO BIOTROP, Bogor. [Indonesian]

Piliarová M, Ondreičková K, Hudcovicová M, Mihálik D, Raic J. 2019. Arbuscular mycorrhizal fungi - their life and function in ecosystem. Agric. 65 (1): 3-15. DOI:10.2478/agri-2019-0001.

Prayudyaningsih R, Sari R, Mangopangi AD. 2019. Isolation of indigenous arbuscular mycorrhizal fungi (AMF) to support revegetation on the nickel post-mining land. IOP Conf Ser Earth Environ Sci 308: 012038. DOI: 10.1088/1755-1315/308/1/012038

Putri AOT, Hadisutrisno B, Wibowo A. 2016. Pengaruh inokulasi mikoriza arbuskular terhadap pertumbuhan bibit dan intensitas penyakit bercak daun cengkeh. J Pemuliaan Tanam Hutan 10 (2): 145-154. [Indonesian]

Setyaningsih L, Dikdayatama FA, Wulandari AS. 2020. Arbuscular mycorrhizal fungi and Rhizobium enhance the growth of Samanea saman (trembesi) planted on gold-mine tailings in Pongkor, West Java, Indonesia. Biodiversitas 21 (2): 611-616. DOI:10.13057/biodiv/d210224.

Suada IK, Prima E, Sritami M, Adiartayasa IW, Susrama IGK, Wirawan IGP. 2018. Isolation and identification of arbuscular mycorrhizal fungi (AMF) in cashew plants (Anacardium occindentale L.) in Datah Village, Abang District of Karangasem Regency. Intl J Biosci Biotechnol 5 (2): 168-175. DOI: 10.24843/IJBB.2018.v05.i02.p10

Sukmawati S, Adnyana A, Suprapta DN, Proborini M, Soni P, Gamawati P, Adinurani. 2021. Multiplication arbuscular mycorrhizal fungi in 
corn (Zea mays L.) with pots culture at greenhouse. E3S Web Conf 226 (00044): 1-10. DOI: 10.1051/e3sconf/202122600044

Thomsen C, Loverock L, Kokkoris V, Holland T, Bowen PA, Hart M 2021. Commercial arbuscular mycorrhizal fungal inoculant failed to establish in a vineyard despite priority advantage. PeerJ 9: e11119. DOI:10.7717/peerj.11119.

Tuheteru FD, Husna A, Arif A, Wulan SA, Kramadibrata K. 2019 Arbuscular mycorrhizal fungi associated with adaptive plants in gold mine tailing. Biodiversitas 20 (11): 3398-3404. DOI: 10.13057/biodiv/d201137.
Wang W, Shi J, Xie Q, Jiang Y, Yu N, Wang E. 2017. Nutrient exchange and regulation in arbuscular mycorrhizal symbiosis. Mol Plant DOI: 10.1016/j.molp.2017.07.012.

Wu Y-H, Wang H, Min Liu BL, Chen X, Ma Y-T, Yan Z-Y. 2021. Effects of native arbuscular mycorrhizae isolated on root biomass and secondary metabolites of Salvia miltiorrhiza Bge. Front Plant Sci 12: 1-13. DOI:10.3389/fpls.2021.617892.

Yusril M, Burhanuddin. 2018. Komunitas fungi mikoriza arbuskula asal tanah gambut pada jeluk berbeda hasil penangkaran inang Zea mays L. dan Pueraria javanica. J Hutan Lestari 6 (1): 90-97. [Indonesian] 